\title{
1. Managing African conflicts: using CSDP missions to cope with terrorism and organized crime
}

\section{Daniela Irrera}

\section{INTRODUCTION}

The European Union (EU) is facing difficult times, marked by a series of political processes, economic trends, social phenomena and global crises that are challenging the fundamentals of the integration project and its capacity to resist this tumult. In the security field, in particular, the EU is trying to reinforce its role as a provider of peace and stability, focusing on geographies where it has the most impact. Africa is a traditionally privileged EU interlocutor and the place where several military and civilian missions have been deployed. In the last decade, since the issue of the European Security Strategy (ESS) and until its most recent inclusion in the European Union Global Strategy (EUGS), the EU has been concerned about terrorist groups' financing sources, the use of violent tactics by criminals, and the effects these phenomena produce within and outside its borders. In a broader perspective and following more recent events, there is a significant concern for solutions that can be enforced on global security. Focusing on EU military and civilian interventions in Africa, particularly the most recent ones in the Sahel region, a large area that includes Mali, Niger, Chad, southern Algeria, southern Libya, Burkina Faso, Darfur, this chapter discusses the use of Common Security and Defence Policy (CSDP) missions as a tool for tackling organized crime and terrorism and strengthening security and stability conditions. As stressed in the introduction, this book intends to analyse specific areas in which major changes have challenged the existing dynamics between Africa's nations and the EU. Concurrent with these aims and based on the current profile of EU relations with Africa which looks like a patchwork of policies and interventions, marked by irrational and short-term concerns, this chapter focuses on security and conflict management as a policy area regarding (a) the current political role the EU is playing in Africa, (b) its ability to deal with the rapidly changing character of local security conditions 
and, most important, (c) its capacity to exercise its leverage in the long term, against other powerful actors.

The chapter is divided into three parts. First, an analysis is presented of the relations between terrorism and organized crime and the danger they represent to global and regional security. Second, the integrated strategy established by the EU is evaluated within the development of CSDP, in Africa and especially focusing on the Sahel region. Last, an empirical assessment of missions deployed in Africa is used to evaluate their impacts as 'counterstrategy' tools and raise awareness of their future effects in the area.

\section{CONNECTIONS BETWEEN ORGANIZED CRIME AND TERRORISM IN A HYBRID SECURITY ENVIRONMENT}

The scholarly debate about the relations between organized crime and terrorism has advanced in the last decades. The first meaningful works have introduced the controversial concept of the crime-terror nexus, to name the connection between two different actors, following distinct aims and using diverse methods, notwithstanding their ability to cooperate for everyday practical purposes. The United Nations Convention Against Transnational Organized Crime defines an organized crime group as actors who usually (a) consist of a collaboration of at least three people; (b) are gathered for a prolonged or indefinite period of time; (c) are suspected or convicted of committing serious criminal offences; and (d) have as their objective the pursuit of profit and/or power (United Nations 2000).

The definition of a terrorist group is more contested and mainly based on the identity and features of the actors (governmental/non-governmental) and the acts of violence. According to the EU Council, a terrorist group is "a structured group of more than two persons, established over a period of time and acting in concert to commit terrorist offences" (EU Council 2002). This violence differs from other forms of political violence, like paramilitarism or insurgency, whose strong political character leads to the organized use of subversion and violence to grasp, invalidate or challenge political control of a region (Oheme 2008; Shoemaker 2014).

The reasons which explain the convergence of interests and some forms of cooperation among entrepreneurial criminals and political terrorists have fascinated criminologists and International Relations scholars. The immediate post-Cold War environment influenced the first investigations on such relations. They stressed the existence of a combination of systemic factors, such as technological progress, globalization of financial markets and organizational factors. These, in particular, influenced the growing transnational dimension of organized crime activities in the 1990s, and the changing nature of terrorism 
regarding the end of the ideological divide (Makarenko 2000, 2004, 2009; Wang 2010). Such combination of factors has facilitated functional connections which Makarenko describes as a continuum, a complex process which starts with the reciprocal adoption of tactics and methods, then proceeds with the merging of the two actors into a new hybrid one and may end with a complete and profound transformation of one entity into the other (Makarenko 2004). The crime-terror nexus emerges as a non-traditional, hybrid threat that may take several forms and depends on a variety of causes and conditions. As for the causes, scholars agree on the functionality of the connection. Rather than making a change in their nature and scope (which would be unnecessary and unproductive), terrorist groups and criminals are more likely to make use of their own respective methods when they are more useful. Illicit trafficking may turn into an easy and quick source of funding for terrorists, whereas terror techniques may be used by criminals in those cases in which more visibility is required (Williams 2002). Despite the evident reciprocity, the first case is more likely to happen, with criminals more ready to connect with terrorists as buyers, than to use their techniques. Based on case studies and empirical investigations, the majority of scholars have paid attention to regions marked by conflict, instability, shadow economies and political failure. These might be considered structural conditions and migration push factors. Such troubled contexts could also favour connections with other forms of armed groups (Pettinger 2001; Cornell 2005; Shelley and Picarelli 2005; Rabasa et al. 2007). Therefore, the linkages among the crime-terror nexus, institutional failure, political instability and civil conflicts have become the basis upon which successive and more sophisticated analyses have developed.

At the end of the Cold War, the growth in the number of civil conflicts drew attention to new security threats, considering that connections among different subversive actors seriously affect all regions and may apply to all security conditions. Regional variations are essential in understanding such efforts. A troubled context, a transitional state or a democratic regime can affect the nexus, its main features, its performances and actions (Makarenko 2007).

Although armed conflicts, political failure and economic deprivation may cause or contribute to crime-terror connections, the latter challenges the state's capacity to provide security to its citizens and regional and international institutions' ability to manage the flow of people across borders. Therefore, all regions, including democratic and stable ones, can be affected.

More recent investigations have tried to re-examine the connections to include more flexible and changing features and to understand the reason a collective response may be required. It is clear that the nexus represents a tangible threat, albeit still tricky to measure, especially in its main components. This makes its implications for regional and global security complex and multi-layered. They need to be analysed over a longer term and from 
a broader perspective, involving those states which are most seriously affected, and those that might suffer indirect, unfavourable effects. At the same time, it demands further investigations of the responses from states and intergovernmental organizations and their abilities to adapt to the rising flexibility of security threats (Irrera 2016).

This overview of the impact of the crime-terror nexus is necessary for the chapter's purposes for two main reasons. On the one hand, the rise of non-traditional and hybrid threats constitutes one of the significant changes that affects security and conflict management. On the other, suffering the results of traditional illicit activities in a larger geographic area, the EU has invested in the stabilization and securitization of its broader neighbourhood.

The ways in which the EU is trying to intervene in the Sahel region, one touched by an extremely high impact of the crime-terror nexus, is a prime example of how the consolidated dynamics between Africa's nations and the EU are challenged and shaped.

\section{THE EU TACKLING NON-TRADITIONAL HYBRID SECURITY THREATS}

Before going deeper into the analysis of the EU's conflict management in the Sahel region, some preliminary observations are required. The impact of the crime-terror nexus on the EU security agenda needs to be defined in terms of the tradition of close cooperation with underdeveloped countries in the fields of aid and relief policies. This tradition offered a ready platform and expertise for improving cooperation between third countries and international organizations regarding drug polices through closer coordination within the EU.

In the document $A$ Secure Europe in a Better World, issued by the European Council in December 2003, the EU High Representative for Common Foreign and Security Policy, Javier Solana, pointed out the primary elements required to build a strong and stable ESS. This set of principles is also used for enhancing the EU capabilities and contributions to global security. The ESS stresses European responsibility for global security, the need for effective multilateralism and the extension of the international rule of law (EU Council 2003; Irrera 2011). The ESS lists five critical threats to Europe: terrorism, the proliferation of weapons of mass destruction (WMD), regional conflicts, failed/failing states and organized crime.

Even with the EU, the main character of its contribution is shifting the process from a Home and Justice Affairs approach to a more comprehensive plan founded on the blurring boundary between internal and external security (Irrera 2018).

The common objective, which is the protection of citizens and states from risks, explains why the threat of terrorism and organized crime was identified 
in the ESS, which had an explicit external perspective and then appears in the set of documents which constitutes what is commonly described as the Internal Security Strategy (ISS) of the Union (EU Commission 2010). The ISS addresses a wide list of security challenges that the European countries face within their domestic borders, including terrorism, organized and cross-border crime, cyber-crime, violence in all its forms, accidents and natural and manufactured disasters. It also implicitly suggests a larger reflection on the European Security Model, consisting of common tools (EU Council 2010, p. 5). According to this document, the EU aims at developing adequate responses, through a coordination of existing agencies (Europol, Eurojust, Frontex, Community Civil Protection Mechanism, and the Counter-Terrorism Coordinator).

The constant use of common actions, in the last decades, has contributed to the international image of the EU as a civilian power. The will to build long-term stabilization, to act through multilateralism, and to be inspired by norms and ideas are the main elements of the global role the EU has developed in the field of promotion of democracy and security (Duchene 1972; Attinà 2013). The more complex set of competences introduced by the Treaty of Lisbon contributed to link this policy to the CSDP and to the civilian and military assets to support peacekeeping missions, conflict prevention and international security outside the Union (TEU art. 42).

In the EUGS (EU Council 2016), since its beginning, the European integration project has been aimed at bringing peace and prosperity to the region and keeping war and conflicts far away from it. Since 2002, the EU has deployed over thirty civilian and military missions in three continents (Europe, Africa and Asia). The EUGS has reaffirmed the need to adapt to the changes in global and regional security and particularly to understand the rise of more hybrid threats (EU Parliament 2012). Hybrid threats may be defined as a "full range of different modes of warfare including conventional capabilities, irregular tactics and formations, terrorist acts including indiscriminate violence and coercion, and criminal disorder. Hybrid Wars can be conducted by both states and a variety of non-state-actors" (Hoffman 2007, p. 8).

If the hybridity dimension is perceived as the new normal, it then influences tools and response policies to cope with them (Facon et al. 2008). Crises - whatever natural and geographical dimensions they may have - are transboundary, as they affect multiple dimensions and require the development of capabilities and tools that involve various actors and competences (Boin 2019). The EU foreign policy of encouraging the coexistence of European, multilateral and bilateral relations, has produced many overlaps and needs to be tailored to the different contexts and preferences as expressed by member states. This means having convergent positions - or at least not too divergent - regarding the more relevant conflicts and crises (from Syria to Donbass) 
and towards the crucial political actors. It seems necessary to re-focus on defence and re-discuss the role of missions. The establishment of Permanent Structured Cooperation on Security and Defence (PESCO), a treaty-based framework to deepen force cooperation among member states, has regularly been presented as the last frontier of joint commitment, yet it is also analysed as a complicated system dependent on states' preferences and national goals, despite the renewed cooperation with NATO and the commitment of the EU to the principles of inclusiveness, reciprocity and decision-making autonomy (Biscop 2018; EU Council 2018a).

The EUGS and the efforts made by PESCO are trying to revitalize the image of the EU as a security provider, able to intervene in multi-layered conditions and using multiple programmes and measures. CSDP missions, in particular, have been recognized as very flexible tools, functional to tackle a wide variety of security challenges, including those linked to irregular migration, terrorism and radicalization, organized crime, border management and maritime security (EU Council 2018b).

The African continent has always been at the core of EU action and one in which more experimental missions could be tested.

\section{THE EU IN AFRICA: CSDP MISSIONS TACKLING ORGANIZED CRIME AND TERRORISM IN THE SAHEL REGION}

As already described, what is commonly defined as the Sahel region is a large area of sub-Saharan Africa, comprising several countries - Mali, Niger, Chad, southern Algeria, southern Libya, Burkina Faso, Darfur - which have experienced long-term civil armed conflicts, political failure and weak economies. As is the case with the rest of the continent, but particularly here, implementing so-called neo-patrimonialism - the vertical distribution of resources around patron-client networks, mainly based on a ruling political party or individual has worsened local conditions (Thompson 2004; Cammack 2007). The lack of sufficient capacity to design long-term policies and to develop administrative support has weakened local institutions, favoured the spread of private use of public resources and boosted institutional corruption (Bach and Gazibo 2012).

In addition to significantly affecting the quality of political, social and economic institutions, this also provided self-legitimation to subversive actors that make use of smuggling and criminal activities to sustain their various goals.

Although challenging to measure empirically, the connection between terrorist and criminal groups evolved since the 2000s and developed in all countries, despite external interventions aimed at managing conflicts and promoting stability. As shown in Table 1.1, there is a wide range of criminal activities that have started to become common practices in sub-Saharan countries. 


\section{Table 1.1 The spread of illicit activities in the Sahel countries}

\begin{tabular}{lcccccc}
\hline & $\begin{array}{l}\text { Drug } \\
\text { trafficking }\end{array}$ & $\begin{array}{l}\text { Kidnap for } \\
\text { ransom }\end{array}$ & $\begin{array}{l}\text { Human } \\
\text { smuggling }\end{array}$ & $\begin{array}{l}\text { Counterfeit } \\
\text { pharmaceuticals }\end{array}$ & $\begin{array}{l}\text { Arms } \\
\text { smuggling }\end{array}$ & $\begin{array}{l}\text { Goldfields } \\
\text { mining }\end{array}$ \\
\hline Mali & $\mathrm{X}$ & $\mathrm{X}$ & & & & \\
Niger & & & $\mathrm{X}$ & $\mathrm{X}$ & & \\
$\begin{array}{l}\text { Southern } \\
\text { Algeria }\end{array}$ & $\mathrm{X}$ & & $\mathrm{X}$ & & $\mathrm{X}$ & \\
$\begin{array}{l}\text { Southern } \\
\text { Libya }\end{array}$ & $\mathrm{X}$ & & $\mathrm{X}$ & $\mathrm{X}$ & $\mathrm{X}$ & \\
Chad & $\mathrm{X}$ & $\mathrm{X}$ & $\mathrm{X}$ & $\mathrm{X}$ & & $\mathrm{X}$ \\
Darfur & $\mathrm{X}$ & & $\mathrm{X}$ & & $\mathrm{X}$ & \\
\hline
\end{tabular}

Source: Micallef et al. (2019).

Drug trafficking, arms and human smuggling, with more local practices like the kidnap-for-ransom industry and goldfields mining, are common to all countries. The absence of state control over the territory and its authority associated with armed groups and mercenaries in various degrees involved in the local conflicts are additional relevant push factors that have contributed to completely subverting the societal systems. Illicit activities, mainly narco-trafficking, and their manipulation by a plethora of subversive actors, have changed social hierarchies in many parts of the region, undermining traditional symmetric relations among the communities (Micallef et al. 2019).

This represents a significant political and social change whose management has negatively impacted the relations between the EU and these African countries. The enormous numbers of refugees and internally displaced persons (IDPs) encourage the exploitation of irregular and human smuggling. The humanitarian dimension of crises in all these countries is deteriorating and requires the application of several tools, programmes and measures (Lacher 2012; Dowd and Raleigh 2013).

The EU Strategy for Security and Development (the so-called Sahel Strategy) was launched in March 2011 as a comprehensive framework for addressing security and development challenges by using several tools. The most recent involvement of the EU in the management of conflicts in Africa has taken the form of establishing the 'G5 Sahel', in December 2014. The Regional Action Plan, adopted by Ministers of Foreign Affairs on 20 April 2015, clarifies the strategic priorities: (1) preventing and countering radicalization, (2) creating appropriate conditions for youth, (3) migration and mobility, and (4) border management and the fight against illicit trafficking and transnational organized crime. 
Through the intervention of a Special Representative, the plan aims at involving all relevant stakeholders of the region, covering local governments, international organizations, civil society and diaspora communities. An important role within this comprehensive strategy is played by CSDP missions, deployed in the region as essential tools for supporting crisis management and conflict prevention.

Military and civilian missions have been tools for preventing or combating terrorism and organized crime. As observed by Van der Ljin, specific activities included in the mandate can target both the consequences and the drivers of such security threats. On one hand, activities targeting consequences are mainly reactive, in that they respond to a threat already identified by reducing and deactivating it. On the other, targeting drivers requires more proactivity since it needs to prevent criminals and terrorist initiatives by addressing the push and pull factors that might produce or enable them. Additionally, missions may target consequences and drivers directly or indirectly, depending on whether the mandate allows them to directly fight, develop or strengthen the capacity of local actors, including the host government, civil society and various communities (Van der Ljin 2018).

The use of civilian missions constitutes a unique feature of the EU's contribution to multilateral cooperation. Developing CSDP missions have followed this last objective. Civilian and integrated missions have been assigned a variety of tasks and activities that address issues such as corruption, development, human rights, the rule of law, deliberately or incidentally overlapping with preventing and combating terrorism and organized crime.

The number of civilian and military missions the EU has deployed outside Europe and particularly in Africa, has increased and developed over the years. Even though they were envisaged as a last resort, civilian missions have been extensively used for tackling non-traditional threats, including crime and terrorist-related issues.

Figure 1.1 displays all missions deployed by the EU, both civilian and military, either already completed or still operating. The EU is more active outside Europe, using its crisis management abilities in countries affected by insurgency and instability. Most civilian missions are associated with executive tasks, for example security sector reform, rule of law or border control, which are inevitably dealing with organized crime, terrorism and insurgency.

In the Sahel region three CSDP missions have been deployed: EUCAP Sahel Niger, EUCAP Sahel Mali and the EU training mission in Mali (EUTM). All three mandates explicitly refer to the fight against terrorism and organized crime and indirectly tackle them, by strengthening the interoperability and the sustainability of local security forces. The deteriorated situation in Mali, in particular, required an additional intervention. Following a request from the local government and according to the UN Security Council resolution 


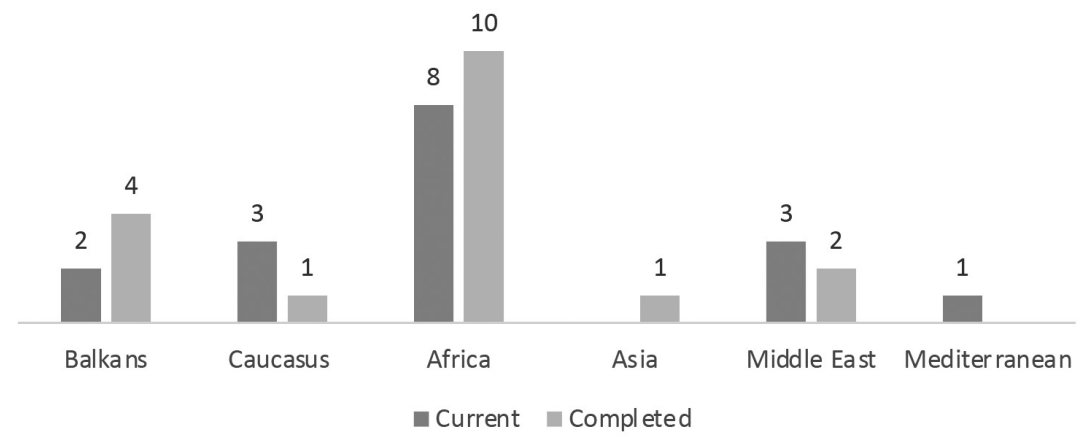

Source: EU External Action 2020.

Figure 1.1 EU civilian and military missions (2020)

Table 1.2 CSDP civilian and military missions deployed in Africa addressing crime-terror issues (2020)

\begin{tabular}{llll}
\hline Mission & Region & C/M & $\begin{array}{l}\text { Reference in the } \\
\text { mandate }\end{array}$ \\
\hline EUAVSEC & South Sudan & Civilian & OC and Terrorism \\
EUNAVFOR & Somalia & Military & Piracy \\
EUTM & Mali & Military & OC and Terrorism \\
EUCAP Sahel Niger & Niger & Civilian & OC and Terrorism \\
EUBAM & Lybia & Civilian & OC and Terrorism \\
\hline
\end{tabular}

Source: EU External Action (2020).

2085 (2012), the EU launched EUTM Mali in 2013, aimed at supporting the rebuilding of the Malian armed forces, matching the humanitarian needs of the population and helping train combat units.

As shown in Table 1.2, references to organized crime (OC) are frequent in documents mandating multilateral missions; however, only a few have been explicitly tasked with addressing it. Other than the missions deployed in the Sahel region, the ones still active in Africa include missions specially shaped to target piracy, illegal migration and radicalization attempts, which are considered as consequences and side effects of criminals' and terrorists' activities and interactions.

The suitability of missions, particularly CSDP ones, to be used for tackling non-traditional security threats is a controversial yet fascinating topic, which will require further research. This is confirmed and enriched by the variety of empirical data and phenomena offered by the missions deployed in Africa, particularly in the Sahel region. Despite these considerations, CSDP missions 
have not always adequately addressed the rapidly changing character of the local security conditions. The EU aspiration to bring peace and prosperity outside its borders, throughout its neighbourhood and all over the world, along with the dream of helping populations exposed to poverty, deprivation and violence, has pushed the EU towards the creation of a complicated political and bureaucratic system, which, over the years, has revealed several inefficiencies.

As has been observed, current external interventions in the Sahel aimed at tackling organized crime and terrorism have been based on a securitized approach, which misses the root causes of the phenomena, particularly the absence of state systems, the dominant neo-patrimonial practices and the scarcity of economic opportunities (Micallef et al. 2019).

Although the EU potential - in terms of nature, structure and competences remains relevant in the region, the inconsistency of its military efforts together with the insufficiency of economic development and aid programmes make the future of sub-Saharan countries extremely uncertain and hinder the EU's capacity to exercise further leverage in the long term, regarding other powerful actors.

\section{CONCLUSIONS: DARK CLOUDS ON THE HORIZONS?}

The main objective of this chapter is to understand whether the nexus between terrorism and organized crime may represent an innovative kind of security threat, able to reduce the impact of the CSDP agenda and to explore whether the missions deployed in the Sahel region can constitute a renewed effort to build a sustainable strategy.

It therefore focuses on security and conflict management as a policy area to address (a) the current political role the EU is playing in Africa, (b) its adequacy to the rapidly changing nature of local security conditions and, most important, (c) its capacity to exercise its leverage in the long term, regarding other powerful actors.

Considering the theoretical assessment and empirical analysis, it is possible to enumerate some assumptions, which will definitively require further research.

First, the strategic alliances between criminals and terrorists constitute a typical case of non-traditional and hybrid security threat, which will continue to affect the global political system. The effects of such alliances may be exacerbated in troubled contexts disturbed by war and insurgency, which can constitute safe havens due to ungoverned entities. However, failed and weak states do not necessarily attract criminals and terrorists, and they can be considered as an additional feature, not an essential one. Although they remain two separate phenomena, the changing nature of global security and 
the increasing effects of globalization have continued to blur the distinctions between politically and criminally motivated violence and to reveal the operational and organizational similarities.

Second, the emergence of hybrid security threats imposes on scholars and policy-makers a reconceptualization of the whole phenomenon, which includes, on the one hand, a flexible set of interactions between separate entities and, on the other, a multi-layered set of issues at the regional and global level.

The challenges the nexus poses to states are marked by their widespread global and regional implications and can be placed on a separate level. The nexus constitutes a threat to a state's capacity to provide security to its citizens and to the regional and international institutions' abilities to manage cross-border flows. This is the reason it is listed among those issues of global concern that require a collective response.

Third, the lack of consideration of such impacts and the failure to manage non-traditional security threats can explain why some conflicts are becoming more intractable and lasting. The hybridity of security and of threats requires a similarly hybrid set of responses. Therefore, the establishment of peace, development and stability, is usually addressed via multi-layered policies, programmes and competences. In this sense, the EU approach could constitute a unique case, providing potential and expertise that could establish an ideal, concrete set of tools.

Fourth, once again, Africa constitutes a laboratory for both threats and security. On one hand, many countries have offered to criminals and terrorists an ideal context - marked by civil conflicts, poverty and corruption - for developing their alliances, exploiting local black markets and enhancing profitable sources of insecurities, such as piracy and illegal migration. On the other, the EU has extensively used CSDP civilian missions for experimenting with cooperation with other actors, focused on specific executive tasks. The EU has built an image of itself as a peace and stability provider in Africa, focusing first on aid and development programmes, and then rapidly shifting to more military and law enforcement interventions. This has neither always nor everywhere improved the ability to manage the rapidly changing characteristics of the local security conditions. The extensive use of CSDP missions has demonstrated that tackling non-traditional security threats in Africa inevitably requires a comprehensive and integrated approach, based on both drivers and consequences, including both direct and indirect activities. An excessively securitized approach, however, may result in an underestimation of the root causes of security issues and, consequently, nullify any potential efforts at intervention. In the long term, if not reversed, this combination of political, military and intelligence approaches can significantly diminish the EU leverage on the African continent. 


\section{REFERENCES}

Attinà, F. (2013). Multilateralism and conflict management: Assessing peace operations. In M. Telò (ed.), Globalisation, Multilateralism, Europe: Towards a Better Global Governance. Abingdon: Routledge, pp. 373-387.

Bach, D. and Gazibo, M. (eds) (2012). Neopatrimonialism in Africa and Beyond. London: Routledge.

Biscop, S. (2018). European defence: Give PESCO a chance. Survival, 60(3), pp. 161-180.

Boin, A. (2019).The transboundary crisis: Why we are unprepared and the road ahead. Journal of Contingencies and Crisis Management, 27(1), pp. 94-99.

Cammack, D. (2007). The logic of African neopatrimonialism: What role for donors? Development Policy Review, 25(5), pp. 599-614.

Cornell, S. E. (2005). The interaction of narcotics and conflict. Journal of Peace Research, 42(6), pp. 751-760.

Dowd, C. and Raleigh, C. (2013). The myth of global Islamic terrorism and local conflict in Mali and the Sahel. African Affairs, 112(448), pp. 498-509.

Duchene, F. (1972). Europe's role in world peace. In R. Mayne (ed.), Europe Tomorrow: Sixteen Europeans Look Ahead. London: Fontana, pp. 32-47.

EU Commission (2010). The EU Internal Security Strategy in Action: Five Steps towards a More Secure Europe. COM(2010) 673 final.

EU Council (2002). Council Framework Decision on Combating Terrorism. OJEU L $164 / 3,22.6 .2002$.

EU Council (2003). A Secure Europe in a Better World. European Security Strategy. December.

EU Council (2010). Draft Internal Security Strategy for the European Union: 'Towards a European Security Model', 7120/10.

EU Council (2016). Shared Vision, Common Action: A Stronger Europe. A Global Strategy for the EU's Foreign and Security Policy. June.

EU Council (2018a). Joint Declaration on EU-NATO Cooperation. Brussels, 10 July. http://www.consilium.europa.eu/media/36096/nato_eu_final_eng.pdf.

EU Council (2018b). Conclusions of the Council and of the Representatives of the Governments of the Member States, meeting within the Council, on the establishment of a Civilian CSDP Compact, Brussels, 19 November. https://www.consilium .europa.eu/media/37027/st14305-en18.pdf.

EU External Action (2020). EU Missions and Operations. https://eeas.europa.eu/sites/ default/files/eu military operations and civilian missions july 2020.pdf.

EU Parliament (2012). Study on Europe's Crime-Terror Nexus: Links between Terrorist and Organised Crime Groups in the European Union. PE 462.503.

Facon, I., Mazzucchi, N. and Patry, J. (2008). Countering Hybrid Threats: EU and the Western Balkans Case. Brussels: European Parliament's Sub-Committee on Security and Defence.

Hoffman, F. (2007). Conflict in the 21st Century: The Rise of Hybrid Wars. Arlington, VA: Potomac Institute for Policy Studies.

Irrera, D. (2011). The EU strategy in tackling organized crime in the framework of multilateralism. Perspectives in European Politics and Society, 12(4), pp. 407-419.

Irrera, D. (2016). The crime-terror-insurgency 'nexus': Implications for multilateral cooperation. In S. Romaniuk and S. Webb (eds), Insurgency and Counterinsurgency in Modern War. Boca Raton, FL: CRC Press, pp. 39-52. 
Irrera, D. (2018). Organised crime: Balancing between national constraints and global necessities. In A. Ripoll Servent and F. Trauner (eds), The Routledge Handbook of Justice and Home Affairs Research. Abingdon: Routledge, pp. 136-145.

Lacher, W. (2012). Organized Crime and Conflict in the Sahel-Sahara Region. Vol. 1. Washington, DC: Carnegie Endowment for International Peace.

Makarenko, T. (2000). Crime and terrorism in Central Asia. Jane's Intelligence Review, 12(7), pp. 16-17.

Makarenko, T. (2004). The crime-terror continuum: Tracing the interplay between transnational organised crime and terrorism. Global Crime, 6(1), pp. 129-145.

Makarenko, T. (2007). Criminal and terrorist networks: Gauging interaction and the resultant impact on counter-terrorism. In E. Brimmer (ed.), Five Dimensions of Homeland and International Security. Baltimore, MD: Johns Hopkins University Press, pp. 57-72.

Makarenko, T. (2009). Terrorist use of organised crime: Operational tool or exacerbating the threat? In F. Allum, F. Longo, D. Irrera and P. Kostakos (eds), Defining and Defying Organised Crime: Discourse, Perceptions, and Reality. New York: Routledge, pp. 180-193.

Micallef, M., Farrah, R. and Bish, A. (2019). After the Storm: Organized Crime across the Sahel-Sahara following the Libyan Revolution and Malian Rebellion. Geneva: Global Initiative against Transnational Organized Crime.

Oheme, C. (2008). Terrorists, insurgents, and criminals: Growing nexus? Studies in Conflict \& Terrorism, 31(1), pp. 80-93.

Pettinger, R. (2000). Mastering Organisational Behaviour. Basingstoke: Palgrave Macmillan.

Rabasa, A., Boraz, S., Chalk, P., Cragin, K., Karasik, T., Moroney, J., O’Brien, K. and Peters, J. (2007). Ungoverned Territories: Understanding and Reducing Terrorism Risks. Santa Monica, CA: RAND Corporation.

Shelley, L. and Picarelli, J. (2005). Methods and motives: Exploring links between transnational organized crime and international terrorism. Trends in Organized Crime, 9(2), pp. 52-67.

Shoemaker, B. (2014). If terrorism and insurgency are the 'weapons of the weak,' why do they sometimes win? International Affairs Forum, 5(1), pp. 59-69.

Thompson, A. (2004). An Introduction to African Politics. London: Routledge.

United Nations (2000). United Nations Convention against Transnational Organised Crime. http://www.unodc.org/documents/treaties/UNTOC/Publications/TOC $\% 20$ Convention/TOCebook-e.pdf.

Van der Ljin, J. (2018). Multilateral Peace Operations and the Challenges of Organized Crime. SIPRI Background Paper, February. https://www.sipri.org/sites/ default/files/2018-02/bp_1802_pko_ngp_iii_no._2_1.pdf.

Wang, P. (2010). The crime-terror nexus: Transformation, alliance, convergence. Asian Social Science, 6(6), pp. 11-20.

Williams, P. (2002). Cooperation among criminal organizations. In M. Berdal and M. Serrano (eds), Transnational Organized Crime and International Security: Business as Usual? Boulder, CO: Lynne Rienner, pp. 67-80. 